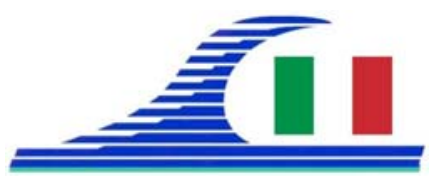

Conférence Méditerranéenne Côtière et Maritime EDITION 3, FERRARA, ITALIA (2015)

Coastal and Maritime Mediterranean Conference

Disponible en ligne - http://www.paralia.fr - Available online

\title{
Regional sediment management strategies. Methods and tools for the Mediterranean region
}

\author{
Christophe BRIERE $^{1}$, Alessio GIARDINO ${ }^{1}$ \\ 1. Deltares, Unit Coastal \& Marine Systems, Boussinesqweg 1, 2629 HV Delft, \\ The Netherlands. \\ christophe.briere@deltares.nl
}

\begin{abstract}
:
Regional administrations and countries that share a coastline need to agree on sustainable management strategies of the available sediment resources. As changes to the natural sediment fluxes can result into trans-boundary issues between the governments, the development of regional sediment budget studies and the assessment of short- and long-term effects of possible interventions using scientifically-based methods and tools are necessary to ensure sustainable, cost-effective and environmentally sound solutions.
\end{abstract}

Keywords: Sediment management, Regional view, Sediment budget analysis, Data management, Monitoring, Numerical models, Visualization and serious gaming.

\section{Introduction}

Sediment is an integral part of the ecosystem and directly affects biodiversity through hydromorphology, habitat formation and associated pollutants. It therefore affects the ecological and chemical status of water bodies. The impacts are particularly evident in shallow water bodies such as rivers, lagoons and coastal areas. Sediment Management goes beyond dealing with (the quantity of) contaminated sediment that needs to be dredged for navigation or construction but is a way of working with nature, finding selfsustaining solutions for the evolution of water bodies in a highly dynamic environment. The integration of sediment management into river basin management plans is the most appropriate context to put this holistic approach into practice.

The Mediterranean coastal areas present unique challenges for sediment management as compared with other EU regional seas; this is coupled to the need for a basin-wide approach, involving both EU and non-EU countries. In most cases the targets for sediment management are strongly connected to different uses of water bodies and to interventions to promote the socio-economic development and competitiveness, such as port dredging and beach nourishment. In such cases, the need for scientificallysound/based methods and tools to inform decisions and policy is crucial in order to promote sustainable, cost-effective and environmentally sound solutions. 
Côtes méditerranéennes menacées :

Risques et défis dans le contexte du changement climatique

\section{Regional sediment management strategies}

The development of regional sediment management strategies is generally based on a sediment budget analysis of the natural system. In addition, possible changes due to anthropogenic action (e.g. construction of a harbour, navigation channel, river dam) or natural causes (e.g. sea level rise, change in storminess) can be evaluated. A sediment budget analysis is basically a mass balance of inputs and outputs of sediment for a predefined area, which gives insight into the relative importance of various sources and losses/sinks. By determining the governing processes and quantifying sediment volumes in the coastal zone, an appropriate long-term sediment management strategy for coastal problems can be developed.

Since direct in-situ measurements of longshore and cross-shore transport rates for sediment budget analysis are not currently possible, indirect methods are generally used to estimate the net longshore and cross-shore transport rates (e.g. bathymetric data, shoreline changes and/or morphodynamic models - see section 3.1). In addition, the assessment of short- and long-term effects of possible interventions can be supported by state-of-the-art software (e.g. UNIBEST-CL+ , Delft3D).

The translation between sediment budget studies to regional sediment management strategies should be then carried out in close cooperation with the local governments. To facilitate the interaction with local stakeholders and the interpretation of numerical modelling results, interactive visualization tools and serious games (section 3.2) can be developed in cooperation with the stakeholders.

\section{Methods and tools}

\subsection{Numerical modelling}

Adequate solutions require knowledge of the underlying morphodynamics and ecological processes. Different approaches and tools have been developed in recent years as design basis to deal with erosion control and management of sandy coasts. The use of different approaches is mainly linked to the spatial and temporal scale of the problem under consideration.

Erosion control at small scale is mainly related to episodic energetic events which may cause large erosion of the dune area, beach and upper shoreface in a few days. The consequences of those events are generally local. Therefore, the most practical and generally applied control solutions are the ones which can have an immediate effect, such as beach nourishments or dune reinforcements. They can be built rapidly but their life time is usually never larger than a few years. Practical beachfill volumes are about $10-30 \mathrm{~m}^{3} / \mathrm{m} / \mathrm{yr}$ for low-energy coasts, as in the Mediterranean area (VAN RIJN, 2009). Several dune erosion models exist in literature (ROELVINK et al., 2009; VAN RIJN, 2009). Those models can be used either following a deterministic approach or probabilistic, accounting also for the stochastic distribution of the model input 
parameters (e.g. waves or profile characteristics; DEN HEIJER et al., 2012). The Figure 1 shows a plot of the dune erosion area (above the storm surge level) after 5 hours as a function of the sediment size and the storm surge level for the Mediterranean wave climate based on the simplified model of VAN RIJN (2009) for the case of waves normal to the coast.

Erosion control at medium scale is mainly of interest for areas affected by structural erosion independently from the needs for immediate intervention. Shoreface nourishments are a useful erosion control measure in those cases as they maintain or increase the sand volume in the nearshore zone and they aim at nourishing the beach area on the long term by natural processes (net onshore transport). Depth-averaged (2D) and quasi-3D numerical models can be used for engineering applications, often in combination with 1D coastline evolutions models (ROELVINK \& WALSTRA, 2004). Long-term natural processes, such as sea level rise, or anthropogenic, such as the closure of entire tidal basins, have an impact on the morphodynamic evolution of the coastline which manifest on a time scale of decades or centuries and on a spatial scale of tens or hundreds of kilometres. A long-term sustainable development requires that the seaward limit of the coastal cell defining the area, where sediment volumes should be maintained, will be progressively shifted seaward, as sediments are supposed to redistribute at larger depths increasing the time scale. One-dimensional coastal evolution models are particularly suitable to assess the long term changes to the coastal areas as they are rather simple and computational efficient. A modified version of those types of models is the recently developed Nourishment Impact Tool (HUISMAN et al., 2012), particularly suitable to assess long-term coastal evolution changes due to the impact of large scale nourishment schemes and the deficit of sand due to sea level rise.

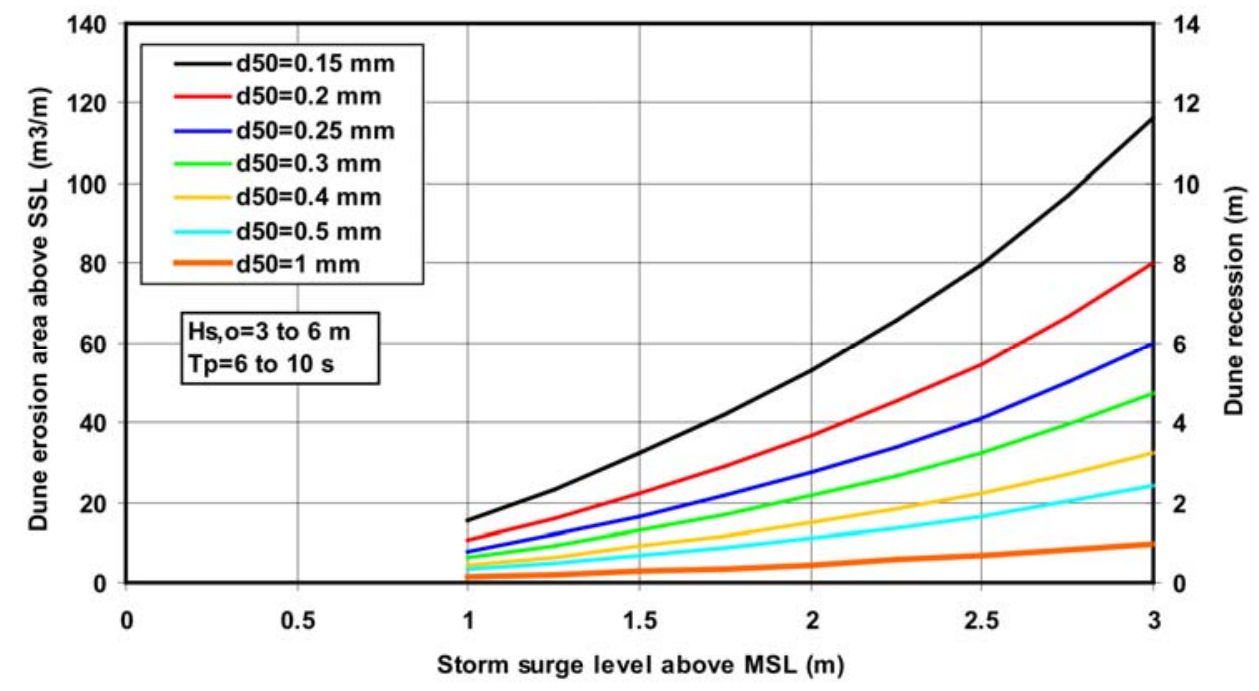

Figure 1. Dune erosion as function of sediment size and storm surge level for the Mediterranean wave climate; from VAN RIJN (2009). 
Côtes méditerranéennes menacées :

Risques et défis dans le contexte du changement climatique

\subsection{Serious gaming}

Serious gaming is becoming an essential tool for strategic planning, training for crisis situations and education. The serious games are typically developed to treat various challenges in delta regions, and combine knowledge about environment and infrastructure, game rules that reflect the span of control of the stakeholders and a realistic visualisation of the area. The serious games are intended to be played by policy makers, students, water managers and the general public.

As an example, the Sand Suppletion game is a strategic game developed for the Dutch coast and simulating the impact of sea level rise on the coast during the 21st century. The player has to provide the economic means and enough sand, to fortify the sandy Dutch coast. The Sustainable Delta game is another strategic game developed for teams of policy makers, with the objective to plan for an uncertain future in a delta area, when sea level rise, population growth and economic development affect water management.

\section{Conclusions}

The development of regional sediment management strategies is generally based on a sediment budget analysis of the natural system that can be supported by state-of-the-art (shoreline evolution and morphodynamic) modelling systems. The translation between sediment budget studies to regional sediment management strategies should be then carried out in close cooperation with the local governments. Serious gaming can facilitate the interaction with the stakeholders. The methods and tools, discussed in this paper and to be presented during the conference with examples of application on Mediterranean coasts, can be used to promote sustainable, cost-effective and environmentally sound solutions.

\section{References}

DEN HEIJER C., BAART F., VAN KONINGSVELD B. (2012), Assessment of dune failure along the Dutch coast using a fully probabilistic approach. Geomorphology, Vol. 143-144, pp 95-103. http://dx.doi.org/10.1016/j.geomorph.2011.09.010

HUISMAN B.J.A., WANG Z.B., DE RONDE J.G., STRONKHORST J., SPRENGERS C.J. (2012). Coastline modelling for nourishment strategy evaluation. Proceedings of the 6th SCACR - International Short Course/Conference on Applied Coastal Research, Lisbon, June 2012. URL : http://www.scacr.eu/component/content/article/7-notizie/15-6th-scacr.

ROELVINK J.A., WALSTRA D.J. (2004). Keeping it simple by using complex models. Advances in Hydrosciences and Engineering, Vol. VI, pp 1-11.

ROELVINK J.A., RENIERS A., VAN DONGEREN A., VAN THIEL DE VRIES J., McCALL R., LESCINSKI J. (2009). Modelling storm impacts on beaches, dunes and barrier islands. Coastal Eng., Vol. 56, pp 1133-1152. http://dx.doi.org/10.1016/j.coastaleng.2009.08.006 VAN RIJN L.C. (2009). Prediction of dune erosion due to storms. Coastal Engineering Vol. 56, pp 441-457. http://dx.doi.org/10.1016/j.coastaleng.2008.10.006 